\title{
Disaster risk profile and existing legal framework of Nepal: floods and landslides
}

This article was published in the following Dove Press journal:

Risk Management and Healthcare Policy

3 September 2015

Number of times this article has been viewed

\section{Surya Gaire \\ Rafael Castro Delgado \\ Pedro Arcos González}

Unit for Research in Emergency and Disaster, Department of Medicine, University of Oviedo, Campus del Cristo, Oviedo, Asturias, Spain
Correspondence: Rafael Castro Delgado Unit for Research in Emergency and Disaster, Department of Medicine, University of Oviedo, Campus del Cristo, Oviedo, Asturias, 33006 Spain

Email rafacastrosamu@yahoo.es

Pedro Arcos González

Unit for Research in Emergency and

Disaster, Department of Medicine,

University of Oviedo, Campus del Cristo,

Oviedo, Asturias, 33006 Spain

Email arcos@uniovi.es
Abstract: Nepal has a complicated geophysical structure that is prone to various kinds of disasters. Nepal ranks the most disaster-prone country in the world and has experienced several natural calamities, causing high property and life losses. Disasters are caused by natural processes, but may be increased by human activities. The overall objective of this paper is to analyze the disaster risk profile and existing legal framework of Nepal. The paper is based on secondary data sources. Major causative factors for floods and landslides are heavy and continuous rainfall, outburst floods, infrastructure failure, and deforestation. Historical data of natural disasters in Nepal show that water-induced disasters have killed hundreds of people and affected thousands every year. Likewise, properties worth millions of US dollars have been damaged. There is an increasing trend toward landslides and floods, which will likely continue to rise if proper intervention is not taken. A positive correlation between water-induced disasters and deaths has been observed. Nepal has a poor Index for Risk Management (INFORM). There are fluctuations in the recording of death data caused by flood and landslides. The Government of Nepal focuses more on the response phase than on the preparedness phase of disasters. The existing disaster management act seems to be weak and outdated. There is a gap in current legal procedure, so the country is in dire need of a comprehensive legal framework. The new proposed act seems to take a much broader approach to disaster management. With a long-term vision of managing disaster risk in the country, the Government of Nepal has begun the Nepal Risk Reduction Consortium (NRRC) in collaboration with development and humanitarian partners. In order to improve the vulnerability of Nepal, an early warning system, mainstreaming disasters with development, research activities, community participation and awareness, and a rainfall monitoring system must all be a focus.

Keywords: risk, vulnerability, risk factors, natural hazards, natural disasters, monsoon rainfall

\section{Introduction}

Nepal is a landlocked country bordered by People's Republic of China to the north and India to the east, west, and south. It is located in the middle portion of the Hindu Kush Himalayan region at the border of the Indian and Eurasian tectonic plates. The country has extreme variations in the natural environment, which ranges from tropical plains to alpine heights, with decreasing elevations from north to south. The northern range consists of mountains of eight peaks higher than 8,000 $\mathrm{m}$ known as the Himalayas, which includes Mt Everest, measuring 8,848 m, toward the border of People's Republic of China. The Himalayas are recognized as a highly active and delicate mountain range. ${ }^{1,2}$ Due to variations in altitude, there are extreme changes in temperature and climatic conditions. In the monsoon season, from June to September, the environment has more precipitation (approximately 80\%) which is converted into rain. Most parts 
of the country have an average annual rainfall of 1,500 $\mathrm{mm}$ to $2,500 \mathrm{~mm}$. Nepal consists of four main rivers that flow from the mountain ranges in the north downstream toward the plain belts in the south. The Himalayan ranges are considered a major source of river water, with more than 6,000 rivers throughout the country. ${ }^{3}$ Nepal has a complicated geophysical structure that is prone to various kinds of disasters, including floods in the lower plain regions and landslides in the hilly and mountainous regions. Nepal ranks the most disaster-prone country in the world and has experienced several natural calamities causing high property and human loss. Flooding and landslides usually take place in the rainy season, which has a greater effect on the loss of property, structures, and lives of people. They cause considerable loss of lives, crops, lands, and infrastructure every year. ${ }^{4}$ The major causes of floods and landslides in Nepal are adverse geoclimatic conditions, massive rainfall, cloudbursts, glacial lake outburst floods, soil erosion, snowmelts, deforestation, water leakage, road construction, and infrastructure failure. 5,6 After performing literature reviews, we found that not many studies have been done on floods and landslides in Nepal. The overall objective of this paper is to develop a disaster risk profile of Nepal focused mainly on water-induced disasters (floods and landslides) and analyze the existing legal framework of the country.

\section{Methodology}

The disaster risk profile of Nepal was developed by reviewing secondary data resources focusing mainly on floods and landslides. The statistics and information were obtained from international disaster sources (EM-DAT and DesInventar) and literature reviews of International reports and journals. National figures and information were obtained from Government of Nepal databases, including those of the Ministry of Home Affairs and Ministry of Irrigation. This paper includes hazards and exposure, vulnerability, and economic losses created due to floods and landslides in the national sectors. The hazard and risk assessment discussed in this paper can help in the generation of a disaster risk-mitigation strategy at the national level. We analyze correlations between water-induced disasters and deaths and critically analyze the existing legal framework of Nepal, with potential recommendations.

We also analyze the Index for Risk Management (INFORM) of Nepal. INFORM is a global, open-source risk assessment for humanitarian crises and disasters. The INFORM model is based on risk concepts published in scientific literature and envisages three dimensions of risk:
Hazard and Exposure, Vulnerability, and Lack of Coping Capacity. ${ }^{7}$ All the information was first compiled in a folder and then processed and analyzed through review. Then, the relevant information was presented in written form accompanied by figures.

\section{Findings \\ Case studies}

\section{Mahakali flood in Darchula District, 2013}

Flash floods and landslides accompanied by massive rainfall from June 16, 2013 heavily affected Nepal's Far-Western Development Region. The flood affected a total of six districts in the country, with Darchula being highly affected. The flood affected approximately 4,400 people and displaced 2,500 in Darchula alone. People were displaced to nearby schools and their relatives' houses. The flood killed a total of nine people. ${ }^{8}$ One hundred and fifty-eight homes were swept away, and more than 200 families were displaced due to the flood. The flood also damaged bridges, highways, and hydro-power facilities. ${ }^{8-10}$ After the flood, the situation of the people in highly affected areas was the worst. The natural disaster response committee in the district urged the government to instantly release Rs 5 million to provide relief to the displaced. People living at the banks of the river were asked to evacuate. ${ }^{11}$ Three rapid response teams were deployed by the District Disaster Relief Committee (DDRC) to identify the number of affected/displaced people and types and amount of relief materials required. Security forces, along with the Nepal Red Cross Society (NRCS), carried out rescue tasks for the affected, helping them to find safe places. Basic materials such as food and clothes were also distributed to the displaced and affected. ${ }^{8}$

\section{Sunkoshi landslide, Jure village of Sindhupalchok District, 2014}

Jure village of Sindhupalchok District, situated $70 \mathrm{~km}$ away from the capital city, was hit by a massive landslide in August 2014, causing the loss of more than 150 lives, loss of more than 115 households, and 436 displaced people. The landslide disrupted $2 \mathrm{~km}$ of Araniko Highway, the only road that connects Nepal to the Chinese border. Infrastructure that was damaged by the landslide produced an artificial lake included a hydropower plant, transmission lines, a poultry farm, a high school, a resort, a community building, school buses, public vehicles, shops and a cement block factory. ${ }^{12,13}$ A total of Rs 130.4 million in physical property damage was observed. Beyond this direct loss of lives and infrastructure, it is alarming to realize the impact and economic loss due to 
blockage of roads and disturbances to livelihoods, economic activities downstream, and electricity power supply. ${ }^{14}$ The Government of Nepal evacuated the communities downstream, declaring the high-risk areas as crisis zones. The government asked local administration, rescue teams, and humanitarian assistants to be alert for evacuation, relocation, and rescue needs and other emergencies. Almost 700 army personnel were deployed in the incident area. The government also coordinated with various national-level organizations as well as with the neighboring countries in seeking help to minimize risks. ${ }^{15}$

\section{The existing legal framework for disaster risk management}

Legal documents (the Natural Calamity (Relief) Act of 1982 $)^{16}$ and the National Strategy for Disaster Risk Management (NSDRM) ${ }^{17}$ of Nepal illustrate a disaster management strategy through various institutional frameworks from central level to local level. The act focuses on executing pre- and post-disaster relief and rescue works by bringing the work of disaster management under the scope and responsibility of the government. NSDRM is based on the Hyogo Framework for Action $2005-2015,{ }^{18}$ which outlines five priority of actions to manage disaster risk in the country. All the government and non-government bodies, including non-governmental organizations (NGOs), international NGOs, and United Nation agencies, are directly or indirectly involved in disaster risk management (DRM). In order to mitigate water-induced disasters, the Department of Water Induced Disaster Prevention (DWIDP) came into existence on February 7, 2000 under the Ministry of Water Resources along with seven divisions and five subdivisions offices. The Government of Nepal has also approved the Water Induced
Disaster Management Policy 2006. ${ }^{19}$ Besides these measures, the Government of Nepal has proposed the National Disaster Response Framework (NDRF), ${ }^{20}$ with clear and quick guidelines for national response to large- and medium-scale disasters in Nepal. The framework has guidelines for effective and comprehensive responses to disasters. Its aim to address the national, regional, district, and local levels in terms of disaster preparedness and response. This document illustrates the proper national and international coordination structure, cluster, and response activities during emergencies. The Government of Nepal also formed the Nepal Risk Reduction Consortium (NRRC) in February 2011, which is supported by the donor communities and focuses on five major "Flagship Programmes", namely, School and Hospital Safety, Emergency Preparedness and Response Capacity, Flood Management in the Koshi River Basin, Integrated Community Based Disaster Risk Reduction, and Policy/Institutional Support for Disaster Risk Management. ${ }^{21}$ The country still lacks a new, practical disaster management act.

\section{Discussion}

Disasters such as floods and landslides occur every year in Nepal, seriously affecting the everyday lives of people and causing enormous damage to physical properties. Every year, such disasters cause fatalities and destroy houses, infrastructure, agricultural land, and crops throughout the country (Table 1). Floods and landslides are the most frequent and deadliest face of disaster in Nepal, after epidemics. A significant number of affected people and serious economic loss due to floods can be seen in the 60 years to 2014 (Figure 1). The loss was caused by 41 flood events in total, which were responsible for 157 deaths and 87,764 affected people per event. Flooding is at the top of the list for loss of lives and

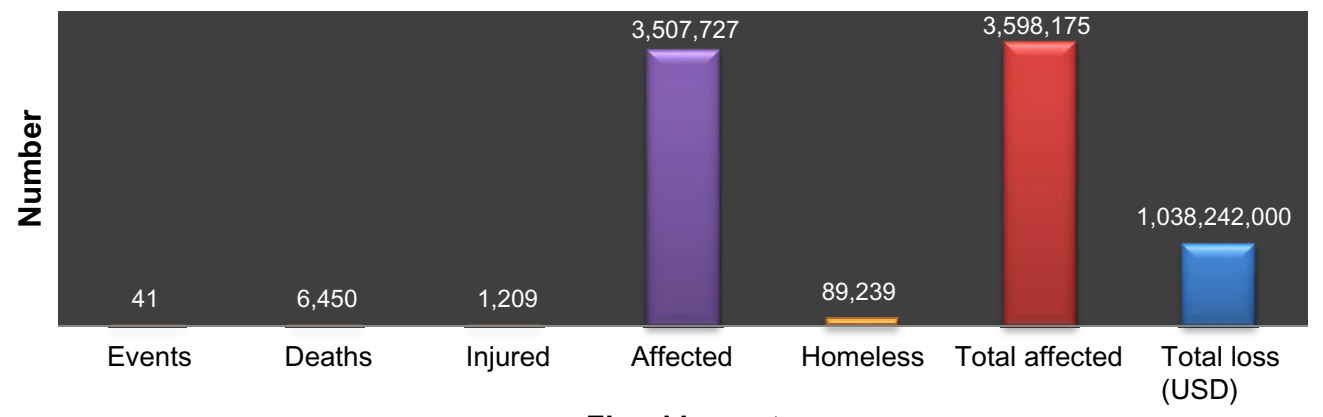

Flood impact

Figure I Impact of floods (1954-20I4).

Notes: The figure illustrates the total affected and total economic loss encountered due to flooding over 60 years. Total number of flood events in the history were $4 \mathrm{I}$. The total number of people killed was 6,450 and the total affected was 3,598,175, while more than USD I billion in economic loss was caused by floods alone. On average, there were 157 deaths and 87,764 people affected per event. Total affected= injured + affected + homeless. Data from EM-DAT: The International Disaster Database [database on the Internet]. Centre for Research on the Epidemiology of Disasters - CRED; 2015.22 
damage to properties. ${ }^{22}$ Flooding has been identified as one of the major destructive disasters in South Asia and has already caused enormous damage to lives and properties. Flooding is also an increasing trend in Bangladesh, India, and Pakistan and is responsible for very high human and economic losses. ${ }^{23}$

Nepal has altogether experienced 14 big landslides since 1967, among them two major landslides that occurred in 1996 and 2010 (Figure 2). In 1996, the Sun Koshi Valley experienced massive floods and landslides that killed 54 people. Similarly, a landslide in 2010 took place in the Madi River in western Nepal, killing more than 100 people and sweeping away many houses. ${ }^{24}$ Landslide-related deaths show an increasing trend over time and are expected to increase in upcoming years if necessary approaches are not taken in a timely manner (Figure 3). There is also an upward trend and positive correlation of number of deaths with disaster events and years (Figures 4 and 5). The trend is expected to increase in coming years if there is no improvement in disaster management activities. A study of landslide trends ${ }^{25}$ shows that this is also an increasing trend, but sufficient data are lacking to confirm this. The study also explains that the highest number of fatalities occur during the monsoon season in most of the South Asian countries. The increase in the death rate could be due to an increase in the population who knowingly or unknowingly continue to reside in the vulnerable areas. It seems that the Government of Nepal should focus on study and research related to floods and landslides to better understand the severity of these disasters and act accordingly. Landslides are a major constraint to national development and vulnerability and are increasing every year. A study of landslides near major highways in Nepal shows that there is a need for an integrated approach to investigation, analysis, design, and construction of mitigated structures in landslide-prone areas. ${ }^{26}$ Floods and landslides are caused by natural processes, but may be increased by human activities such as poor infrastructure construction. Adverse geoclimatic conditions, massive rainfall, cloudbursts, glacial lake outburst floods, soil erosion, and snowmelts are some common natural causes of floods and landslides in Nepal. Likewise, deforestation, water leakage, road construction, and infrastructure failure are triggering factors for floods and landslides. ${ }^{5,6}$ Among these factors, confined rainfall during the monsoon season has a high negative impact on the lives of people; every year, hundreds of people die and thousands are displaced, and there are adverse effects on the socioeconomy of the country as a whole. If the flood takes place frequently or regularly every year, the impact gets higher. On the other hand, a lack of knowledge about disasters among the people and lack of provision of mitigation measures adopted by the Government of Nepal could be a reason for millions of affected people and billions of dollars worth of damage to properties (Figure 1).

Intense rainfall during the monsoon season is regarded as one of the main triggering factors for landslides. ${ }^{6,24,25,27}$ A study done in the eastern Himalayas of Nepal illustrates that there is a considerable relationship between monsoon rainfall and occurrence of landslides. The results show that continuous rainfall of 5 to 10 days is usually responsible for landslides in the Himalayas of Nepal. ${ }^{6}$ Precipitation is the major cause of flooding in all the countries in South Asia that are more vulnerable to flooding. ${ }^{23}$ If the rainfall takes place for example for 10 days, then there is high possibility of landslide occurring. A certain amount of water in the soil can be threshold for landslide to occur. A careful examination of this threshold can be beneficial in taking appropriate preventive measures. In terms of emergency preparedness, early warning by an information dissemination system after the critical amount of rainfall can help in saving lives and properties to a significant degree. ${ }^{27}$ The flood and landslide

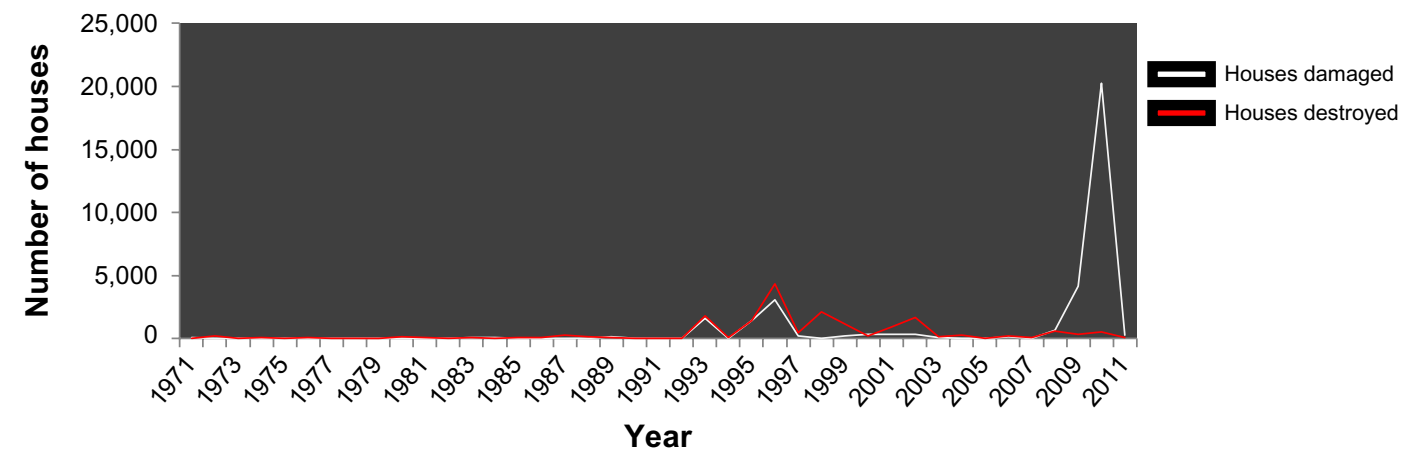

Figure 2 Number of houses damaged and destroyed by landslides (197I-20II).

Notes: The above line graph shows the frequency of houses destroyed and damaged by landslides over 40 years. The highest peak of houses damaged is seen in 2010 , which covers $59.67 \%$. Similarly, the total destroyed houses were 18,49I, out of which 4,339 (23.46\%) were in the year 1996. In each of 1993, 1995, 1996, 1998, 1999, and 2002, more than I,000 houses were destroyed ( $N=18,491)$. Similarly, in each of 1993, 1995, 1996, 2009, and 2010, more than I,000 houses were damaged ( $N=33,960)$. Data from DesInventar. Inventory system of the effects of disasters [database on the Internet]. Colombia: Corporación OSSO; $2011 .^{28}$ 


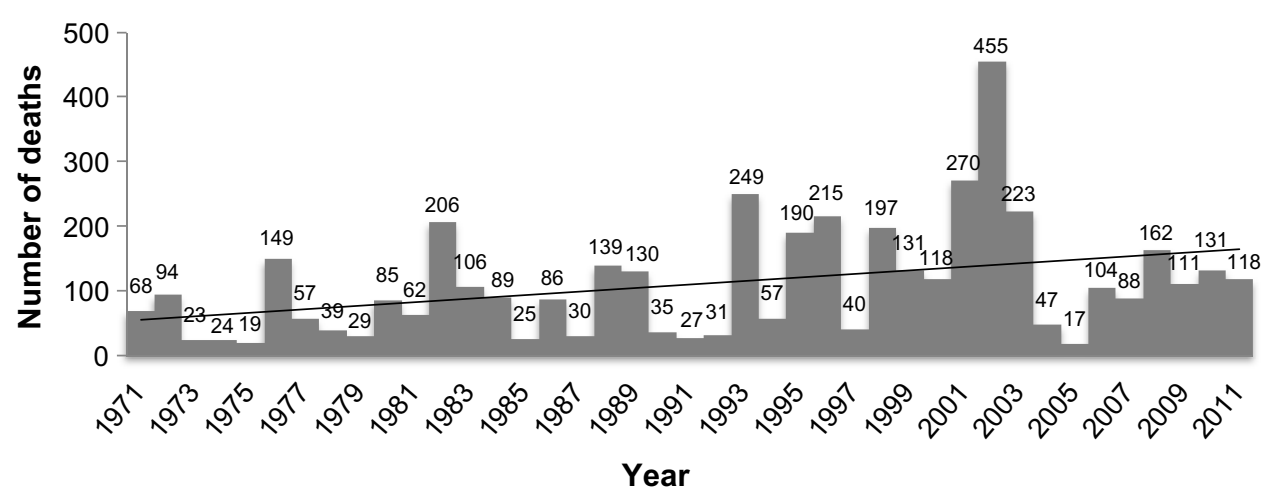

Figure 3 Number of deaths caused due to landslides (197I-20II).

Notes: In 2002, the highest number of deaths (I5.65\%) due to landslides were recorded, followed by deaths in 200 I (9.28\%), 1993 (8.5\%), and 2003 (7.7\%) ( $\mathrm{N}=4,476)$. These percentages were measured out of total deaths. There is an increasing trend in deaths caused due to landslides in Nepal. Data from DesInventar. Inventory system of the effects of disasters [database on the Internet]. Colombia: Corporación OSSO; 201 I. ${ }^{22}$

case studies described in the present paper clearly illustrate that there has been a little progress made in terms of response of disaster; however, the country lacks major preparedness and an early warning system (EWS).

Some districts have been ranked on the basis of their vulnerability to flooding and landslides (Table 2). Nepal is divided into 75 districts and three ecological regions, namely the Terai, Hill, and Mountain Regions. Hills and mountains are more prone to landslides, and Terai is vulnerable to floods. The level of risk of and vulnerability to landslides depends on which ecological region the district is situated in. The ranking of disasters and analysis of vulnerability caused by these disasters can help in planning mitigation measures on a priority basis. Lack of resources in the country could be the cause for not being able to carry out the processes. According to INFORM, ${ }^{7}$ physical exposure to floods in Nepal is at the highest level. Nepal has acquired 10 points out of 10 in terms of physical exposure to floods. This illustrates the worst condition and a high probability of loss of lives and economic loss due to floods. INFORM Risk, Hazard and Exposure, Vulnerability, and Lack of Coping Capacity are 5.2, 5.5, 4.1, and 6.55 (Table 3), respectively, with 10 being the worst. There is a decreasing trend in INFORM

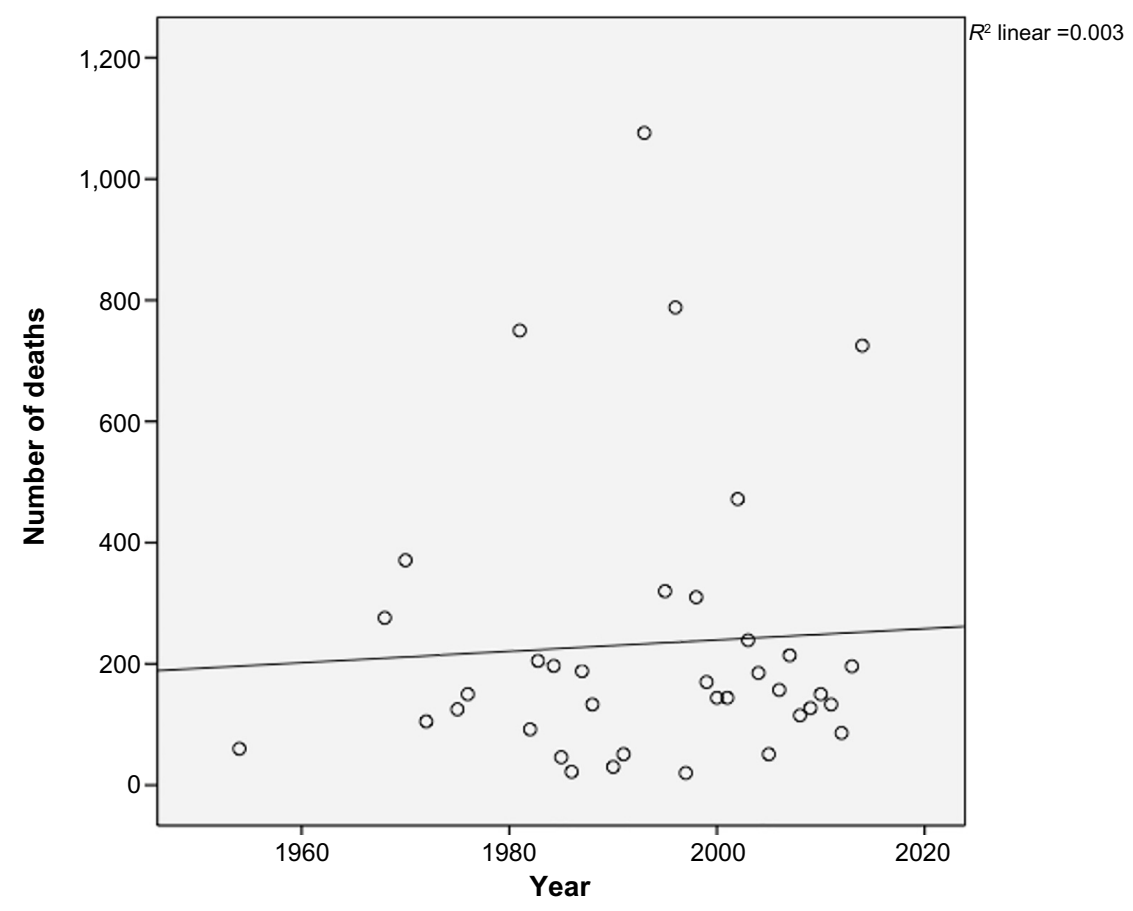

Figure 4 Association between number of deaths and increasing year.

Notes: The scatter plot illustrates that there is an upward trend and positive correlation in deaths due to floods and landslides every year. If the deaths continue in the same way, they are expected to be higher in coming years. Data from EM-DAT: The International Disaster Database [database on the Internet]. Centre for Research on the Epidemiology of Disasters - CRED; 2015.22 


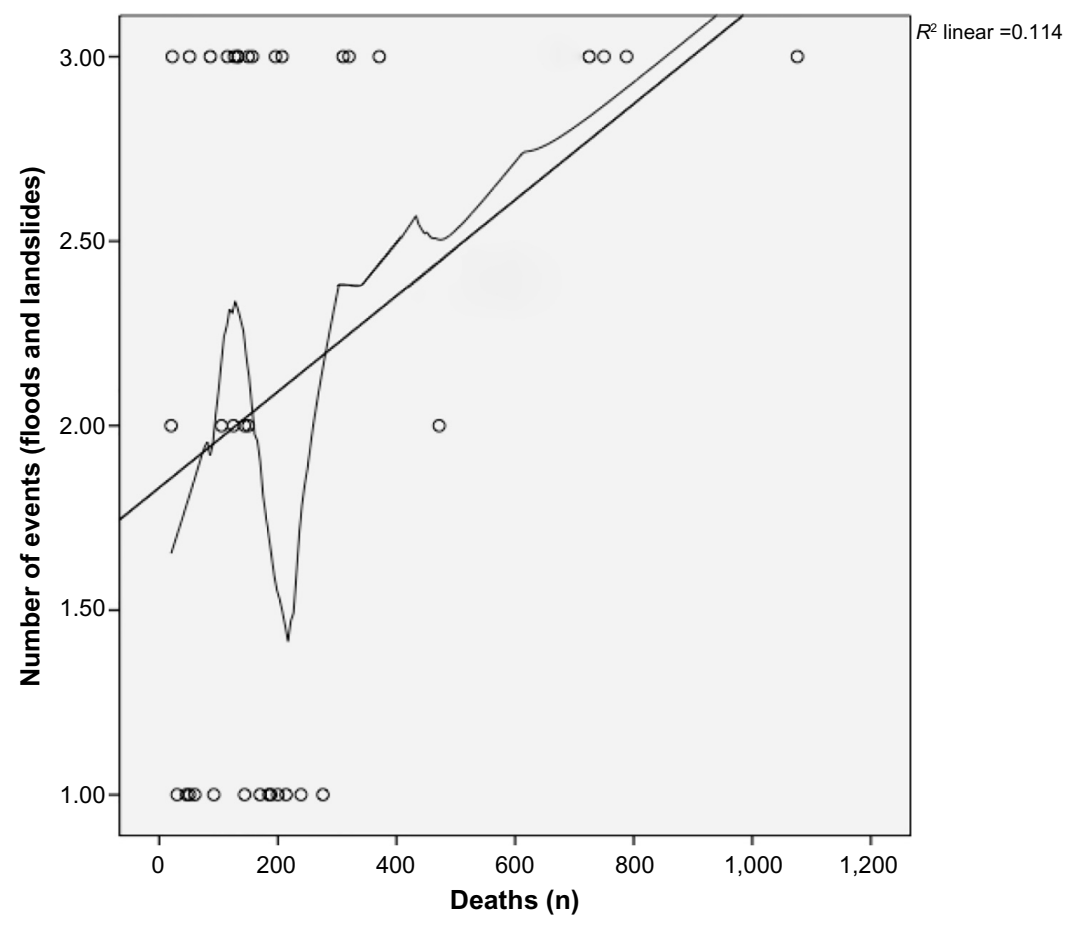

Figure 5 Association between the number of events (floods and landslides) and deaths caused by them every year.

Notes: The scatter plot shows that there is a positive correlation between floods and landslides and deaths of people. It indicates that there is a positive linear relationship between number of events and deaths caused by them. Data from EM-DAT: The International Disaster Database [database on the Internet]. Centre for Research on the Epidemiology of Disasters - CRED; 20I5. ${ }^{22}$

Risk, Hazard and Exposure, and Vulnerability, but Lack of Coping Capacity has remained the same since the last 3-year rating. The INFORM Risk is relatively very high, as it falls in the red mark. Neighboring countries (India and Bangladesh) also fall very high in the index, but People's Republic of
China and Bhutan have a medium INFORM Risk. ${ }^{7}$ The coping capacity of Nepal has not been able to progress over the last couple of years. The Lack of Coping Capacity of Nepal is 6.55 , which is relatively poor. In many disaster-prone rural areas where there are limited resources, the promotion of

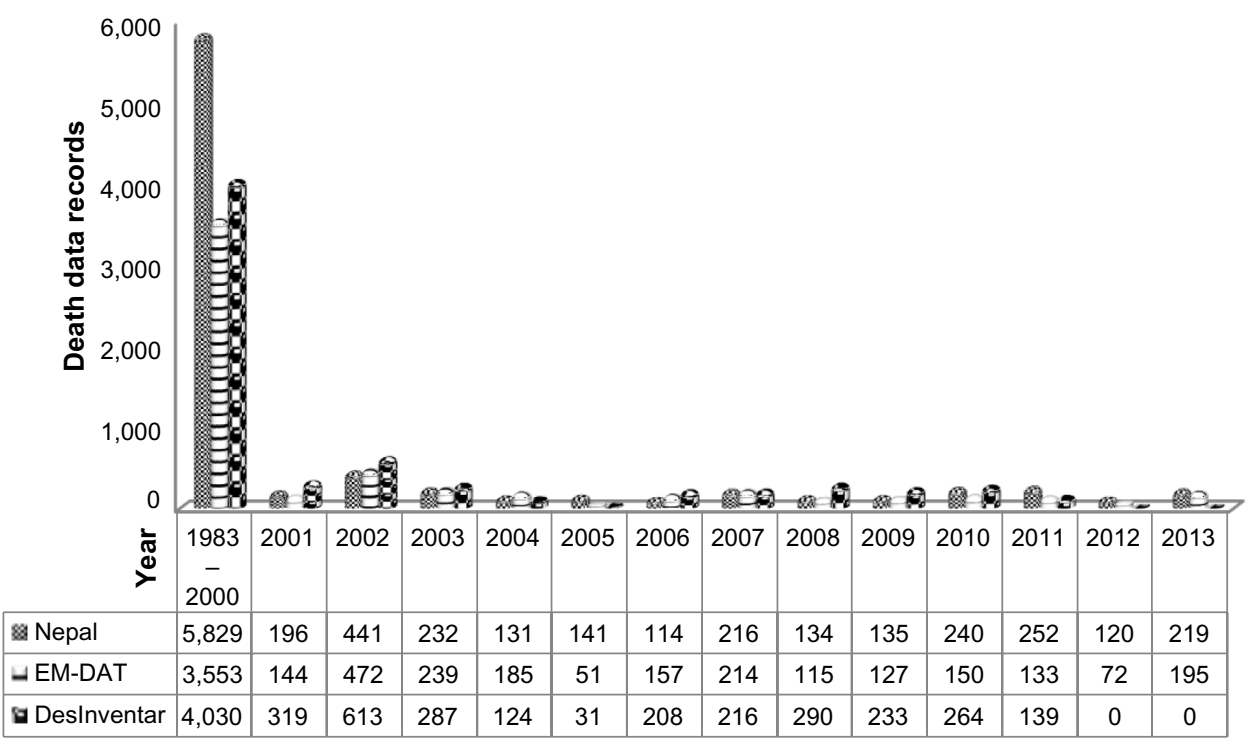

Figure 6 Comparison of international data and national data records regarding the number of deaths. .2,28,29 $^{2}$

Notes: A comparison of death records due to floods and landslides between international databases and national databases is shown in the figure. The record regarding the number of deaths for the same event fluctuated in different data sources. A higher number of death records can be seen in Nepal data (1983-2000), while lower records are seen in EM-DAT and DesInventar databases. Similarly, a higher record is seen in DesInventar than in other sources (2008). 
Table I Losses (n) from water-induced disasters (1983-2013)

\begin{tabular}{|c|c|c|c|c|c|c|c|}
\hline \multirow[t]{2}{*}{ Year } & \multicolumn{2}{|c|}{ People } & \multirow[t]{2}{*}{ Livestock lost } & \multirow[t]{2}{*}{ Houses destroyed } & \multirow[t]{2}{*}{ Families affected } & \multirow{2}{*}{$\begin{array}{l}\text { Land affected } \\
\left(\mathrm{km}^{2}\right)\end{array}$} & \multirow{2}{*}{$\begin{array}{l}\text { Economic loss } \\
\text { (NPR), million }\end{array}$} \\
\hline & Dead & Injured & & & & & \\
\hline $1983-2013$ & 8,343 & 2,031 & 86,770 & 228,561 & 668,246 & $12 \mid, 386$ & 22,872 \\
\hline Average/year & 278 & 67 & 2,892 & 7,618 & 22,274 & 4,046 & 762 \\
\hline
\end{tabular}

Notes: A review of 30 years of data (1983-20I3) shows that water-induced disasters have killed 278 people, damaged 67 houses, affected 2,892 families, affected 4,046 km ${ }^{2}$ of land, and caused a loss of NPR 762 million (approximately USD 7,855,670) every year. The total estimated loss until 2013 was NPR 22,872 million (approximately USD 235,793,8I4). Data from Ministry of Irrigation, DWIDP. Department of Water Induced Disaster Prevention Bulletin. Construction. 2006. ${ }^{29}$

Abbreviation: NPR, Nepalese Rupee.

action by community people may be central to coping with disasters. The Government of Nepal has been following a trend of providing relief work only during a disaster, especially during the monsoon floods and landslides. This type of approach cannot be long lasting; instead, people should be made alert and aware of an effective preparedness approach at the community level throughout the year. This may be effective in managing the disaster response in case of delays in response by the authorities.

Data from international databases, ie, EM-DAT and DesInventar, are compared with the dataset received from the Ministry of Home Affairs (Table 4), Government of Nepal, which is the focal ministry for collecting and compiling all disaster-related data. The data include death records due to floods from 1983 to 2013. There is no equivalent in number of deaths record in national and international sources. The reason for the fluctuation may be due to underreporting or overreporting of the data. Variations in data source may also play an important role in this fluctuation. A smaller disaster is unlikely to draw a great deal of attention at the national level, possibly due to a lack of media attention. ${ }^{30}$ Besides, international databases might have some criteria in recording national data to their databases. For example, EM-DAT only records a disaster if it kills at least ten people or affects at least 100 people or if the country declares a state of emergency, ${ }^{22}$ while DesInventar records even small disasters that have only local-level effects.

During a disaster, health facilities such as hospitals play a significant role. ${ }^{31}$ Hospitals are well known as the most important health facility for minimizing the risks related to disasters. Emergency preparedness guidelines for risk management of a health institution must be focused on providing services during critical situations. The provision of triage, evaluation, and medical management of multiple casualties may make it more effective to have these facilities during disaster, than not to have them. ${ }^{32}$ To improve the situation, health facilities mapping in disaster-prone areas should be done when planning disaster response activities.

Looking at the milestones in DRM, Nepal has actively participated in DRM activities (Table 4), but most of these are limited only to blueprint. The focus on the implementation part is very weak. This may be due to lack of internal resources and less focus on preparedness than on response.

National legal documents ${ }^{16,17}$ illustrate a disaster management strategy through various institutional frameworks from a central to a local level. However, the current disaster management act missed out the provision of proactive mitigation measures such as preparedness and mainstreaming of hazard reduction in the development process. The disaster

Table 2 Top ten districts for flood and landslide events in 2012/2013

\begin{tabular}{|c|c|c|c|c|c|c|c|c|}
\hline \multirow[t]{2}{*}{ Rank } & \multicolumn{4}{|l|}{ Floods } & \multicolumn{4}{|l|}{ Landslides } \\
\hline & District & Region & Events(n) & Rank factor & District & Region & Events(n) & Rank factor \\
\hline I & Kaski & WDR & 6 & I & Nuwakot & CDR & 35 & I \\
\hline 2 & Dang & MWDR & 5 & 0.9 & Illam & EDR & 7 & 0.9 \\
\hline 3 & Banke & MWDR & 4 & 0.8 & Humla & MWDR & 6 & 0.8 \\
\hline 4 & Humla & MWDR & 4 & 0.7 & Sankhuwasabha & EDR & 6 & 0.7 \\
\hline 5 & Ilam & EDR & 4 & 0.6 & Taplejung & EDR & 6 & 0.6 \\
\hline 6 & Sankhuwasabha & EDR & 3 & 0.5 & Myagdi & WDR & 5 & 0.5 \\
\hline 7 & Kailali & FWDR & 2 & 0.4 & Jajarkot & MWDR & 3 & 0.4 \\
\hline 8 & Kathmandu & CDR & 2 & 0.3 & Surkhet & MWDR & 3 & 0.3 \\
\hline 9 & Nawalparasi & WDR & 2 & 0.2 & Dhading & CDR & 2 & 0.2 \\
\hline 10 & Parbat & WDR & 2 & 0.1 & Gorkha & WDR & 2 & 0.1 \\
\hline
\end{tabular}

Notes: The top ten districts that are prone to floods and landslides (2012/2013) are shown in the table. Kaski District in the WDR of Nepal is considered more prone to floods, with rank factor I. Likewise, Nuwakot in the CDR is ranked as the number I landslide-prone district. Data from Ministry of Irrigation, DWIDP. Department of Water Induced Disaster Prevention Bulletin. Construction. 2006. ${ }^{29}$

Abbreviations: CDR, Central Development Regions; EDR, Eastern Development Regions; FWDR, Far-Western Development Regions; MWDR, Mid-Western Development Region; WDR, Western Development Regions. 
Table 3 INFORM data for Nepal

\begin{tabular}{llll}
\hline & Value & Rank & Trend (3 years) \\
\hline INFORM Risk & 5.2 & 28 & Decreasing \\
Hazard and Exposure & 5.5 & 35 & Decreasing \\
Vulnerability & 4.1 & 68 & Decreasing \\
Lack of Coping Capacity & 6.55 & 54 & No change \\
\hline
\end{tabular}

Notes: INFORM Risk, Hazard and Exposure, Vulnerability, and Lack of Coping Capacity are 5.2, 5.5, 4.I, and 6.55, respectively, with 10 being the worst. There is a decreasing trend in INFORM Risk, Hazard and Exposure, and Vulnerability, but Lack of Coping Capacity has remained as it is since last 3 years. Data from INFORM Country Risk Profile: Nepal. Index for Risk Management (INFORM); 2004.7

Abbreviation: INFORM, Index for Risk Management.

management act seems to be weak and traditional. Existing legal documents focus more on response than preparedness. For developing countries like Nepal, disaster preparedness is always a better option than response..$^{30}$ The act does not clearly mention the roles, responsibilities, and ethics of national and international responders. The existing law does not clearly direct the presence of foreign assistance during a time of disaster nor termination of their assistance after the disaster. There are also no specific provisions in Nepalese law to enable legal facilities to assist states in times of disaster. Meanwhile, there is also a lack in law about minimum standards of goods and packaging to be maintained in disaster relief goods and services. Similarly, a minimum standard should be maintained for medicine and medical equipment coming into the country. Although there is a law to ensure a minimum standard of medicine and medical equipment, the implementation has been poor. The policy is typically tilted toward response activities, but there is still a need for disaster mitigation and preparedness approaches. In a report published by the NRCS, ${ }^{33}$ provisions for making international appeals are not clearly made and, most of the time, ad hoc decisions are made for disaster response. The report has highlighted the gap in current legal procedure and the need for a comprehensive legal framework. Misuse of disaster relief funds has been noted in the country, so an appropriate monitoring mechanism for those collected funds is necessary, but is lacking in the law. The paper also focuses on the need for an EWS in the country and in transboundary regions. An EWS is being adopted as a risk reduction project in Nepal. However, the institutional framework is not as transparent as it needs to be. The policy focus on EWS is as yet flexible in implementation. The Government of Nepal is very cooperative with international agencies during disasters. It is always better to identify the potential humanitarian agencies with their respective working areas prior to a disaster. The Government of Nepal has been receiving assistance in cash or in kind when disaster happens in the country. There should be one

Table 4 Milestones in disaster risk management in Nepal ${ }^{2,4}$

\begin{tabular}{ll}
\hline Year & Initiatives/activities \\
\hline 1982 & NCRA promulgated the first legal initiative \\
1984 & UNDP study about the threats of disaster and the need for foreign assistance conducted \\
1987 & Disaster unit under the MoHA established \\
1989 & NCRA I 982 amended (first amendment) \\
1990 & Strategy for training on disaster management prepared \\
1990 & National committee to celebrate the decade of the I990s as the decade of international disaster reduction \\
1991 & Comprehensive disaster management plan prepared \\
1992 & Second amendment of NCRA I 982 ratified \\
1993 & Training of government officials in collaboration with UNDP organized \\
$1993 / 1994$ & Training on disaster management conducted by USAID and ADPC, Bangkok, organized as per request of MoHA \\
1994 & Action plan prepared with the help of UNDP \\
1996 & UNDP's disaster management capacity-building program begun \\
2001 & Department of Narcotics Control and Disaster Management under MoHA established \\
2002 & National Development Plan (2002-2007), emphasizing irrigation and water-induced disaster preparedness and \\
& natural disaster management \\
2003 & Disaster impact assessments of development projects made mandatory in the Tenth National Plan \\
2005 & National Water Plan development, and Nepal participated in the Hyogo Conference \\
2006 & Approval of water-induced disaster management policy \\
2007 & Drafts on acts, policies, and strategies on disaster management in Nepal prepared \\
2008 & NSDRM prepared \\
2009 & NSDRM approved by Government of Nepal \\
2011 & Five-year Disaster Risk Reduction strategic framework developed by USAID and Nepal Disaster Risk Reduction \\
& Office \\
2014 & Disaster Risk Management Policy developed \\
\hline
\end{tabular}

Notes: The table shows the milestones in disaster risk management in Nepal from the first disaster act to a recent policy framework that has been taken into consideration. It shows that Nepal is actively participating in disaster management activities.

Abbreviations: ADPC, Asian Disaster Preparedness Center; MoHA, Ministry of Home Affairs; NCRA, Natural Calamity Relief Act; NSDRM, National Strategy for Disaster Risk Management; UNDP, United Nations Development Project; USAID, United States Agency for International Development. 
funnel method of monitoring incoming agencies. We also recommend having particular provisions for those who are interested in assisting. The NSDRM focuses on capacity building of local actors related to disaster, which is missing in disaster act 1982. The law also needs to establish concrete plans to mobilize local NGOs and community based organizations during disasters.

It has been more than a decade of not having local leaders to look after community-level activities, including disaster planning. This is one of the weaknesses of the country for not being able to empower local communities through stable local leaders. At the district level, 21 districts still need health contingency planning exercises, and 54 others are waiting for training. ${ }^{34}$ The draft of a new disaster management act was prepared a couple of years ago, but approval is still pending. This act seems to take a much broader approach to disaster management, coordination, and collaboration, along with responsibilities for implementation by the selected authorities. This could have saved a few lives if it was approved on time. With a long-term vision toward managing disaster risk in the country, the Government of Nepal has begun the NRRC, which can help Nepal gain disaster-resilient communities through its programs.

\section{Recommendations and conclusion}

All in all, the findings of this report may be very useful in reducing the loss of lives and socioeconomic structures due to water-induced disasters in various vulnerable areas of Nepal. It may also be useful in prioritizing the districts that are prone to floods and landslides for interventions and adoption of a new multifunctional law in the country.

Recommendations that can help Nepal to prevent loss of lives, infrastructure, and economy due to water-induced disasters are as follows.

A campaign to strengthen community empowerment and awareness related to floods and landslides, particularly in high-risk zones, needs to be established. Forming community-based rescue teams and providing them appropriate training can save more lives by quick action during the response phase of a disaster.

Disasters can be mainstreamed with development works to avoid future destruction caused by poor construction of infrastructure. Such construction should be properly planned and evaluated to avoid possible effects and consequences from floods and landslides.

Integration of disaster preparedness in the school curriculum and regular broadcasts from media can be effective in the long run. Overall, there has been some progress made in flood and landslide preparedness, but there still remain lots of things to be done.

For appropriate hazard-vulnerability analysis and establishment of EWSs, there is an urgent need for a standard, uniform source of information. Research in disaster areas must be promoted to analyze the severity of floods and intervene accordingly. EWSs can be implemented in collaboration with community-based organizations that can build a certain level of communication sharing in disaster-prone areas of the country. Responsible authorities and channels of communication for EWSs can be identified in local, national, and international communities.

Continuous rainfall monitoring should be done through modern monitoring gauges that can help to detect and assess the vulnerability of land to landslides. Similarly, local-level flood hazard mapping done with the frequently flooding river basins can save lives and properties.

The country is in dire need of a clear legal framework and act for natural disaster management. Almost all the time, postdisaster rescue operations are given priority, and the national law also focuses mainly on the aftermath of a disaster. The management of disasters should be carried out routinely and must be revised in the national law to make it more effective.

\section{Acknowledgments}

Surya Gaire would like to express immense gratitude to his helpful friends for their contribution to the disaster risk profile work. Finally, yet importantly, Surya Gaire would like to express his heartfelt thanks to the entire management committee of the University of Oviedo and all the lecturers who have played a vital role in completion of this work.

\section{Author Contributions}

All authors contributed toward data analysis, drafting and critically revising the paper and agree to be accountable for all aspects of the work.

\section{Disclosure}

The authors report no conflicts of interest in this work.

\section{References}

1. Central Bureau of Statistics (CBS). National Population and Housing Census 2011 (National Report). Kathmandu: Government of Nepal; 2012. Available from http://cbs.gov.np/wp-content/uploads/2012/11/ National\%20Report.pdf. Accessed: November 3, 2014.

2. National Society for Earthquake Technology - Nepal (NSET). Global Assessment of Risk: Nepal Country Report. Kathmandu; 2008. Available from http://www.gripweb.org/gripweb/sites/default/files/CSA_Report_ Nepal_Draft_2011-01-03.pdf. Accessed November 3, 2014. 
3. National Society for Earthquake Technology - Nepal (NSET). Nepal Country Report: Global Assessment of Risk. Kathmandu: United Nations Development Programme; 2009. Available from http://www. undp.org/content/dam/nepal/docs/reports/UNDP_NP_Nepal\%20 Country\%20Report.pdf. Accessed November 4, 2014.

4. Country Profile, hazard profile, disaster profile [webpage on the Internet]. Government of Nepal; 2011. Available from: http://www.saarcsadkn.org/countries/nepal/country_profile.aspx. Accessed November 16, 2014.

5. Khanal NR, Shrestha M, Ghimire M, editors. Preparing for Flood Disaster: Mapping and Assessing Hazard in the Ratu Watershed, Nepal. Nepal: International Centre for Integrated Mountain Development (ICIMOD) and New Delhi: United Nations Educational Scientific and Cultural Organization (UNESCO); 2007.

6. Dahal RK. Rainfall-induced landslides in Nepal. International Journal of Erosion Control Engineering. 2012;5(1):1-8.

7. INFORM Country Risk Profile: Nepal. Index for Risk Management (INFORM); 2004. Available from: http://www.inform-index.org/ Portals/0/InfoRM/2015/Country_Profiles/NPL.pdf. Accessed: July 15, 2015.

8. World Health Organization (WHO). Flash Floods and Land Slides in Far Western Region, Nepal. WHO Nepal; 2013. Available from: http:// www.searo.who.int/entity/emergencies/crises/Flash_Floods___FWR_-_ Nepal_-_EHA_-_WCO_-_ESR_1.pdf. Accessed November 24, 2014.

9. Mahakali flood sweeps entire settlement in Darchula; One killed, district headquarters at risk; 23 workers rescued in Kanchanpur [webpage on the Internet]. Image Channel; 2013. Available from: http://imagechannels. com/news/details/28635/Mahakaliflood-sweeps-entire-settlement-inDarchula-One-killed-district-headquarters-at-risk-23-workers-rescuedin-Kanchanpur. Accessed November 15, 2014.

10. Recent Natural Disasters. Nepal's Mahakali floods Darchula, red flag placed, emergency declared. 2013. Available from: http://www. disaster-report.com/2013/06/nepals-mahakali-floods-darchula-red.html. Accessed: November 24, 2014.

11. Nepalnews.com. Mahakali flood displaces 2,500 [webpage on the Internet]. ReliefWeb; 2013. Available from: http://reliefweb.int/report/ nepal/mahakali-flood-displaces-2500. Accessed November 15, 2014.

12. Information Bulletin. Nepal and India: Landslides and Floods. International Federation of Red Cross and Red Crescent Societies (IFRC); 2014. Available from https://www.ifrc.org/docs/Appeals/rpts14/ IBNPIN1s030814.pdf. Accessed: December 21, 2014.

13. Khanal NR, Gurung DR. ICIMOD Rapid Field Investigation: Jure Landslide Dam Site Jure, Sindhupalchowk District, Nepal. ICIMOD. Available from: http://www.icimod.org/resource/14483. Accessed November 24, 2014.

14. Report on Field Visit of Sunkoshi/Bhotekosh Landslide Affected Area. DPNet Nepal; 2014. Available from: http://www.dpnet.org.np/ docs/reportManagement/c1177e6cb4970cf8b32f2a789a05d67c.pdf. Accessed: January 15, 2015.

15. Landslip dams sunkoshi river [webpage on the Internet]. eKantipur; 2014. Available from: http://www.ekantipur.com/the-kathmandupost/2014/08/02/topstory/landslip-dams-sunkoshi-river/265685.html. Accessed November 24, 2014.

16. Natural Calamity (Relief) Act 2039 BS (1982). Nepal Law Commission; 1982. Available from: http://www.nrcs.org/sites/default/files/pro-doc/ natural-calamity-relief-act.pdf. Accessed July 15, 2015.

17. National Strategy for Disaster Risk Management, 2009. Government of Nepal, Ministry of Home Affairs; 2009. Available from: http://www. nrcs.org/sites/default/files/pro-doc/NSDRM\%20Nepal.pdf. Accessed: November 26, 2014.

18. United Nations. International Strategy for Disaster Reduction Hyogo Framework for Action 2005-2015: Building the Resilience of Nations. World Conf Disaster Reduct. 2005. Available from: http://www.unisdr. org/files/1037_hyogoframeworkforactionenglish.pdf. Accessed: January 25, 2015.
19. Department of Water Induced Disaster Prevention. Construction. Government of Nepal, Ministry of Irrigation. 2014. Available from: http://www.dwidp.gov.np/uploads/document/file/DWIDP_Bulletin_All_ Pages_Final.pdf. Accessed: November 24, 2014.

20. Government T, July HA. National Disaster Response Framework (NDRF). 2013. Available from: https://www.ifrc.org/docs/IDRL/2011\%20 National\%20Disaster\%20Response\%20Framework\%20(unofficial $\% 20$ translation\%20).pdf. Accessed. November, 262014.

21. Nepal Risk Reduction Consortium. Flagship Programmes. Nepal Risk Reduction Consortium (NRRC). Available from: http://www.preventionweb. net/files/32158_32158nrrcflagshipprogrammesforweb19.pdf. Accessed.

22. EM-DAT: The International Disaster Database [database on the Internet]. Centre for Research on the Epidemiology of Disasters - CRED; 2015. Available from: http://www.emdat.be. Accessed January 1, 2015.

23. Mirza MMQ. Climate change, flooding in South Asia and implications. Reg Environ Chang. 2011;11(Suppl 1):95-107.

24. Khanal NR, Koirala A, Gurung S, et al. Madi River, Nepal: landslide dam outburst flood risk management. In: Shrestha AB, Bajracharya SR, editors. Case Studies on Flash Flood Risk Management in the Himalayas: In Support of Specific Flash Flood Policies. 2013;42-47.

25. Petley DN, Hearn GJ, Hart A, et al. Trends in landslide occurrence in Nepal. Nat Hazards (Dordr). 2007;43(1):23-44.

26. Dahal RK, Hasegawa S, Masuda T, Yamanaka M. Roadside slope failures in Nepal during torrential rainfall and their mitigation. In: Marui H, editor. Disaster Mitigation of Debris Flows, Slope Failures and Landslides: Proceedings of the INTERPRAEVENT International Symposium Disaster Mitigation of Debris Flows, Slope Failures and Landslides Held on September 25 --27, 2006, in Niijigata, Japan. Tokyo: Universal Academy Press; 2006;503-514.

27. Paudel PP, Omura H, Kubota T, Morita K. Landslide damage and disaster management system in Nepal. Disaster Prev Manag. 2003; 12(5):413-419.

28. DesInventar. Inventory system of the effects of disasters [database on the Internet]. Colombia: Corporación OSSO; 2011. Available from: http://www.desinventar.org/en/database. Accessed January 1, 2014.

29. Ministry of Irrigation, DWIDP. Department of Water Induced Disaster Prevention Bulletin. Construction. 2006. Available from: http://www. dwidp.gov.np/uploads/document/file/DWIDP_Review_2013_Book_ All_Pages_Final.pdf. Accessed: January 5, 2015.

30. Farthing DW, Ware M. When it comes to mapping developing countries, disaster preparedness is better than disaster response. 2006. Available from: http://www.researchgate.net/publication/235747321_When_ it_comes_to_mapping_developing_countries_disaster_preparedness_is_better_than_disaster_response. Accessed: July 15. 2015.

31. Ahuja RB, Bhattacharya S. Burns in the developing world and burn disasters. BMJ. 2004;329(7463):447-449.

32. Jacobs LM Jr, Goody MM, Sinclair A. The role of a trauma center in disaster management. J Trauma. 1983;23(8):697-701.

33. International Disaster Response Law (IDRL) in Nepal. Nepal Red Cross Society; 2011. Available from: http://www.ifrc.org/ PageFiles/93552/1213100-Nepal Red Cross-IDRL Report-EN-LR04. pdf. Accessed. July 15, 2015.

34. IRIN. Health sector focus for earthquake preparedness [webpage on the Internet]. ReliefWeb; 2011. Available from: http://reliefweb.int/report/nepal/ health-sector-focus-earthquake-preparedness. Accessed July 15, 2015. 
Risk Management and Healthcare Policy

Dovepress

\section{Publish your work in this journal}

Risk Management and Healthcare Policy is an international, peerreviewed, open access journal focusing on all aspects of public health, policy, and preventative measures to promote good health and improve morbidity and mortality in the population. The journal welcomes submitted papers covering original research, basic science, clinical \& epidemio- logical studies, reviews and evaluations, guidelines, expert opinion and commentary, case reports and extended reports. The manuscript management system is completely online and includes a very quick and fair peerreview system, which is all easy to use. Visit http://www.dovepress.com/ testimonials.php to read real quotes from published authors.

Submit your manuscript here: http://www.dovepress.com/risk-management-and-healthcare-policy-journal 